Горан Васин

Универзитет у Новом Саду

Филозофски факултет

Одсек за историју

keano11@yahoo.com
Оригинални научни рад

примљено: 1. јул 2011

прихваћено: 1. октобар 2011

\title{
ПРЕЧАНСКА ШТАМПА О ПРОГЛАШЕЊУ ЦРНЕ ГОРЕ ЗА КРАЉЕВИНУ*
}

Сажетак: Уздизање Црне Горе у ранг краљевине и прослава педесетогодишњице владавине Николе Петровића важна је тема писања српске штампе. Политичка анализа овог поступка црногорског владара била је незаобилазна прича из броја у број, на првом месту новосадске Заставе и загребачког Србобрана. О Цетињској прослави у овим листовима писало се крајње негативно, често и врло непримерено, политички острашћено. Владар Црне Горе описан је као аутократа, који нема слуха за грађанске и демократске реформе. Са друге стране, лист новосадских либерала Браник писао је потпуно афирмативно о јубилеју и заслугама будућег краља Николе за Српство. Политичке страсти српске пречанске сцене тако су и у вези са овим догађајем показале да је било каква форма јединства радикала, самосталаца и либерала готово немогућа.

Кључне речи: Црна Гора, Никола Петровић Његош, краљевина, прослава, Цетиње, Русија, пречани, штампа.

Педесетогодишњица владавине Николе Петровића Његоша обележена је у државно-правном смислу на највиши могући начин. Црна Гора је уздигнута у ранг краљевине. Књаз Никола постао је краљ. Овај важан моменат историје Црне Горе, налазио се у средишту пажње целокупне српске штампе, како у Србији тако и у Аустроугарској. Читавих месец дана на страницама Заставе, Браника, Србобрана писано је о манифестацијама и свечаностима одржаним од 15. до 17. августа 1910. на Цетињу. О величини и важности овог догађаја сведочи податак да су припреме почеле још током марта 1910, када је оформљен Одбор за прославу. Чланови овог Централног одбора били су: митрополит Митрофан Бан (председник), Божидар Перазић, војвода Гавро Вуковић, Живко Драговић, ђакон Иво Калуђеровић, Јован Матановић, Лабуд Гојнић, Лазар Мијушковић, Марко Ђукановић, Медо Лукачевић, Мило Дожић, Ристо В. Поповић, Славо Рамадановић, Стеван Радосављевић и Филип Јерговић. Поред Централног одбора формирани су још и Одбор за дочек и размештај гостију, Одбор за кићење вароши, осветљење и бакљаду, Одбор за уређење вароши, Одбор за одржавање прописаног поретка. Све је сведочило о томе 
да се спрема велика државна прослава која је требало да симболише просперитет и напредак Црне Горе у времену од када се на њеном челу налазио књаз Никола. ${ }^{1}$ Одбор је током пет месеци рада, односно припрема овог важног догађаја, одржао неколико десетина седница на којима се расправљало о најразличитијим темама и аспектима Цетињске прославе. ${ }^{2}$

Пре централне манифестације на Цетињу је одржана и једна мања, али такође важна прослава - обележавање јубилеја 25 година архипастирског рада митрополита црногорско-приморског Митрофана Бана, 6. априла 1910. Књаз Никола и књагиња Милена су поздравили заслужног архијереја. ${ }^{3}$ У својој беседи

\footnotetext{
* Рад је настао као фазни резултат републичког пројекта број 177002 под називом Војвођански простор у контексту европске историје.

${ }^{1}$ Приликом прославе четрдесет година владавине књаза Николе, која је органозована 1900, одржане су такође многобројне манифестације. Тако је већ тада разматрана опција да се Црна Гора уздигне у државно-правном смислу на виши ранг. Током 1898, књаз је писао Валтазару Богишићу о Манифесту који треба да претходи проглашењу Црне Горе за велику књажевину. Према истом плану црногорски књажеви имају и почасну титулу краљевско височанство. Сам Никола Петровић је тврдио да оваква промена приличи једној независној држави, јер књажевско достојанство носе и владари вазалних држава. Неке државе на Балкану већ имају и краљевске титуле (Србија и Румунија), тако да проглашење Црне Горе за велику књажевину није противно европским нормама, а и не вређа ничије достојанство или поредак европских владарских кућа. Треба напоменути да Црна Гора, као наследница Зете, само враћа своја стара знамења, писао је књаз. У допуни овог предлога, Валтазар Богишић је додао да у Немачкој постоји 6 великих кнежевина и да најмања има свега 316 км2, а од независних држава такви примери су Лихтенштајн и Монако. Међутим, после Богишићевих интервенција и дужег промишљања од ове идеје се 1898. ипак одустало. Како се сећао Симо Поповић, Никола Петровић је имао идеју да се прогласи за српског краља, а наслов велика књажевина за Црну Гору суштински није била никаква промена, али јесте био корак уназад у тежњама за проглашење краљевине. Прослава 40 година књажеве владавине била је повезана са поновним идејама о промени владарског звања. Гавро Вуковић је сматрао да је материјално стање у самој земљи било врло лоше и да су недостајала средства да се држава уздигне на ранг краљевине. Ипак, донета је одлука да владар почне са употребом звања краљевско височанство. Прослава је била скромнија од манифестација које су уследиле 1910. Најпре је 15. августа 1900. освећен новоподигнути велелепни храм Св. Василија Острошког у Никшићу, уз присуство књаза, његове породице и свих народних првака. Потом је за Никољдан 1900. изашао проглас Државног савета о додељивању титуле краљевско височанство књазу Николи Петровићу Његошу (Симо Поповић, Мемоари, Подгорица 1995, 411-432; Гавро Вуковић, Мемоари, књ, 2, Цетиње 1985, 187-228).

${ }^{2}$ Одбор је пред собом имао важан задатак да организује сваки детаљ манифестације која је требало да Црну Гору представи као јаку и просперитетну државу, нагласак је био на повезаности народа, династије и војске, уз истицање личности владара као обједињујућег фактора поменуте државне целине. Одржано је преко 50 седница Централног одбора. Расправљало се о свим сегментима прославе. Не дневном реду биле су набавке осветљења, цвећа, потом храна, позоришне представе, превоз и смештај гостију, израда слика и албума будућег краљевског пара и целокупне прославе. Посебно се разговарало и о финансијској страни прославе. Детаљна упутства су добили и представници свих министарстава и сви чиновници који су према плану имали да учествују у прослави. Сви свештеници такође су добили наредбу о времену и начину служења благодарења у данима Цетињског јубилеја. Посебна пажња посвећена је доласку страних делегација и њиховом боравку у Црној Гори. Одређене су и обавезе војника који су били изабрани за учешће на дефилеу на Обилића пољани (Velimir Vujačić, Obnova crnogorskog kraljevstva i jubilarne svečanosti 1910, Zbornik dokumenata, Cetinje 2010, 24-60, 79, 83-84, 88-90, 105, 110-111, 119-120, 124-125, 146-152, 187-188, 201, 223, 270-271).

${ }^{3}$ Цела манифестација је почела благодарењем које је служио епископ рашко-захумски Кирило Митровић уз присуство чланова књажевске породице и руске делегације (отправник послова Дјаченко, војни агент Потапов и конзул у Скадру Стројев). Митрополит Митрофан Бан (Главати, Грбаљ, 15. 3. 1841 - Цетиње 30. 9. 1920) спадао је у ред најистакнутијих архијереја Српске православне цркве свог времена. Још 1862. као искушеник борави у манастиру Праскавици, а замонашен је у Савини од стране далматинског епископа Стефана Кнежевића 1865. године. Био је учесник Бокељског устанка 1869, тако да је морао да пређе из Аустругарске у Црну Гору, где је постављен за игумана манастира Мораче (1869-1879). У борбама око манастира 1877. нарочито се истакао. Током 1878. водио је преговоре са Нури-бегом око предаје Колашина. У време 1878-1879. постао је цетињски архимандрит и учитељ престолонаследника Данила. Администрира Митрополијом (1882) и Захумско-рашком епархијом (1882-1884). За митрополита Црне Горе и Брда је изабран 1884. Хиротонисан је у Санкт Петербургу (у Исакијевском
} 
владар је напоменуо да митрополит једини од свих епископа у целом Српству има медаљу Обилића, симбол јунаштва и ратништва, што говори о свим заслугама и врлинама слављеника. Истакнуто је такође да су везе Русије и Црне Горе нераскидиве. Књаз је здравицу подигао у част цара Николаја, а цар је митрополита одликовао медаљом Светог Александра Невског другог степена. ${ }^{4}$ Прослава јубилеја митрополита Митрофана била је лепа увертира за августовске свечаности које је требало да промовишу Црну Гору у ред европских краљевина. Књаз Никола је уочи прославе намеравао да поправи свој однос према опозицији, пошто су политичке тензије током 1908-1909. досегле проблематичан ниво. Нарочито је помиловањем неких појединаца кренуо у смеру отопљавања политичке климе, укључивањем чланова Народне странке у неке од одбора за прославу, као што су Шако Петровић Његош (председник Уставотворне скупштине из 1905. и први председник Народне скупштине из 1906), војвода Гавро Вуковић, Јанко Тошковић, Милош Радовић и други. Са друге стране, чланови Народне странке желели су да докажу да нису против књаза Николе. ${ }^{5}$

сабору) уз присуство цара Александра и његове породице. Пуно је радио на побољшању стања у цркви. Такође у организационом смислу начинио је неколико крупних промена у функционисању Цркве. У време ратова 1912-1918. био је председник Црвеног крста и активно је радио на скупљању материјалне помоћи за војнике и бринуо се о рањеницима као духовни пастир. Приликом уједињења и обнове Патријаршије имао је значајну улогу (Српски биографски речник, том 1, Нови Сад 2004, 398-399).

${ }_{4}^{4}$ Честитку су упутили и краљ Петар Карађорђевић, митрополит Димитрије са епикопатом, прота Ђурић, прота Алекса Илић, Удружење новинара Србије, будући архијереји СПЦ Гаврило Дожић, Севастијан Дабовић, Симеон Поповић из манастира Дајбабе (данас светитељ Српске цркве), све свештенство из Црне Горе, потом Антоније Хаџић из Новог Сада, епископ бачки Митрофан, професори Карловачке богословије, као и стотине свештеника, монаха и поштовалаца овог великог архијереја.

${ }^{5}$ Помиловање политичких осућеника било је везано за Бомбашку аферу и Колашински процес. Ова два важна догађаја чинила су велику препреку у односима Србије и Црне Горе. Политичка напетост између две српске државе имала је многобројне форме. Црногорска омладина у Београду нарочито је била критична према стању у Црној Гори. Сличан је био и став водећих српских листова у Аустроугарској. Напетости на релацији Омладина - опозиција и књаз Никола видљиве су још од доношења Устава 1905. Услед унутрашње политике књаза Николе, коју је Омладина доживљавала као недемократску, дошло је до неминовног сукоба две идеје и две концепције. Књаз је за Лучиндан 1905. обавестио Црногорце да ће им о Никољдану подарити Устав. Прожимана идејом јачих уставних и политичких слобода у Црној Гори и револуционарних стремљења ка јединству свих Срба Омладина је у Београду штампала Ријечи универзитетске омладине у виду брошуре (21 новембар 1905). Иако је на самом почетку критика садржана у Ријечи била блага, она ускоро постаје један од камена међаша између књаза и Омладине. На изборима 27. новембра 1905. прошли су углавном државни службеници. Ипак, о уставу није било расправе у Скупштини. Уставом је књаз суштински већи део власти задржао у својим рукама (Црна Гора је постајала уставна, али не и парламентарна држава), тако да је априла 1906., поново издат манифест универзитетске омладине. Највише су се истицали Марко Даковић и Тодор Божовић. Током 1906. формирана је и прва модерна политичка странка у Црној Гори. Програм странке је написан по узору на програм Радикалне странке у Србији и Српске народне радикалне странке у Монархији. По својој суштини странка није била антидинастичка. Она се напросто залагала за модернизацију политичког живота у Црној Гори. Књаз ипак није благонаклоно прихватао опозицију, па је под притиском део посланика морао да напусти Клуб народне странке (присталице књаза оформиле су Праву народну странку, тзв. праваши). Маја 1907. појављује се проглас српске омладине из Црне Горе који је оштријим тоном напао књаза. Са друге стране влада Лазара Томановића је сматрала да иза ове групације стоји управо званична Србија. Притисак на присталице Народне странке бивао је све јачи, а донета је и одлука да странка не учествује на изборима. Ускоро је и Тодор Божовић послао за Црну Гору бомбе (15 комада). Конкретан план за употребу ових бомби није постојао. Народна странка и њени прваци нису ступили у контакт са Даковићем и Божовићем. Ускоро је особа која је чувала бомбе предала исте полицији на Цетињу. Књаз Никола је у свом говору у Скупштини нагласио да је откривена завера која је за циљ имала уништење и обезглављивање династије. Убрзо је на предлог књаза изгласан Закон о устројству суда за суђење анархистичким злочинцима. Оптужбе да су бомбе набављене у Београду изазвале су бурну реакцију штампе у Србији. Београдски листови су оптужили цетињску полицију да је режирала аферу. 
Раније светковине оваквог карактера у Црној Гори биле су скромније, па се постављало питање на који начин се може финансирати овај велики догађај. Материјално стање Кнежевине није било на завидном нивоу, о чему је штампа доста писала. Сјај и помпа који су пратили проглашење Краљевине наметали су огромне финансијске издатке. Било је потребно завршити Дом књажеве владе (Владин дом), потом Народну скупштину, и почети зидање новог Саборног храма на Цетињу. У ту сврху подигнут је кредит у вредности од 6 милиона перпера код енглеских банака. Уочи саме прославе спроведено је ново осветљење, а и завршетак нових репрезентативних зграда на Цетињу дао је у потпуности нову слику црногорске престонице. ${ }^{6}$ Од значаја за проглашење Краљевине је и податак да је Никола Петровић својим родбинским везама стекао доста наклоности европских владарских породица. ${ }^{7}$ Велики број европских дворова послао је своје представнике на Цетиње. Од владара били су присутни бугарски цар Фердинанд и италијански краљ Виктор Емануел. Посебно интересантну здравицу владар Црне Горе одржао је бугарском госту, истичући да цени бугарску независност и да према Бугарима гаји посебну љубав, коју ми Срби најближа браћа гајимо према Вама и вамем народу. ${ }^{8}$ На

Суђење на Цетињу је трајало од 25. маја до 13. јуна 1908, и оптужене су 52 особе. Сведок оптужбе, аустроугарски агент Ђорђе Настић, оптужио је друштво Словенски југ, престолонаследника Ђорђа и фактички Владу у Београду. Међу осуђенима је 6 добило смртне казне, а 43 временске, укључујући и 13 оснивача Народне странке. Убрзо се десила још једна афера. У Подгорици је 14. јануара 1909. формирано револуционарно удружење, које је за основу програма одредило абдикацију књаза Николе и довођење на престо престолонаследника Данила. Статут је саставио пензионисани мајор Никола Митровић. Црна Гора мора постати слободна и демократска, што се има извести мирним путем, а ако не буде друге могућности и револуцијом, стајало је у Статуту. Како је полиција почела да открива организацију, поручник Никола Ђиновић је непромишљено кренуо у акцију, која се завршила неуспехом. Ускоро је формиран Велики војни суд у Колашину. Оптужена је 161 особа. На смрт је осуђено њих 11. Влада на Цетињу затражила је од Србије да испоручи особе које су осуђене у ова два процеса, а односи две државе били су на доста лошем нивоу уочи јубилеја 1910. Јавно мњење широм Аустроугарске и Србије сматрало је да се помиловање политичких осуђеника у Црној Гори мора спровести у потпуности. Књаз Никола је проценио да се мора искористити размимоилажење чланства Београдске студентске омладине и Народне странке у Црној Гори (група Марка Даковића) да се направи избалансирана селекција на списку за помиловања (Јован Маркуш, Народна странка 1906-1918, Подгорица 2006, 309-318, 326-332, 347-361; Новица Ражнатовић, Лична власт књаза и политичке борбе, у: Историја српског народа, VI/1, 219-224, 226-231; Никола Шкеровић, Црна Гора на освитку 20 вијека, Београд 1964, 85-86, 90-92, 101-118, 190-197, 255-269, 557-558; Василије Крестић, Радош Љушић, Програми и статути српских политичких странака до 1918, Београд 1991, 373-381; Радош Љушић, Српска државност 19. века, Београд 2008, 407-412; Симо Поповић, Мемоари, 507-549).

6 У споменици која је штампана на Цетињу поводом педесет година владавине Николе Петровића и обнове краљевине нарочито је истакнут велики напредак црногорске војске, потом више од 100 обновљених и подигнутих цркава на територији Црне Горе, унапређење школа, финансија, путева и привреде. Црна Гора је понос Српства, просперитетна држава, која је за 50 година књажеве владавине направила крупне помаке на свим пољима друштвеног и политичког живота, стоји у овом важном историјском извору (Вид.: Педесет година на престолу Црне Горе, Цетиње 1910, приредио Лазар Томановић).

${ }^{7}$ Никола Петровић је током низа година склопио више бракова својих кћери са члановима европских владарских породица. Најпре је 1883. удао Зорку за Петра Карађорђевића, будућег краља Србије, потом 1889. Милицу за Петра Николајевића, великог књаза, исте 1889. Анастасију (Стану) за великог кнеза Ђорђа Романовског, а други пут 1907. за великог кнеза Николаја Николајевича Романова. Ћерку Јелену удао је 1896. за прица Викторија Емануела, будућег краља Италије, и Јелену за Франца Јозефа Хесенског. Његов син престолонаследник Данило био је ожењен Јутом (Милицом), ћерком војводе од Мекленбурга (Јован Маркуш, Краљевина Црна Гора, Споменица јубилеја 1910, Подгорица 2010, 100-101).

${ }^{8}$ У Србији је са друге стране нарочито лоше примљена вест о похвалним тоновима које је књаз Никола упутио Фердинанду Кобуршком. Сматрало се да је бугарски владар крајње антисрпски настројен и да лично жели да из својих интереса умањи значај Србије и на прво место у међудржавним односима постави Црну Гору. Са друге стране ни Црна Гора није желела да изостави своје интересе на Балкану. 
Цетињу је боравила и делегација Краљевине Србије коју је водио престолонаследник Александар са министром војним генералом Степом Степановићем. Дочекали су их градоначелник Цетиња Јанко Дрљевић и сердар Јанко Вукотић. ${ }^{9}$ Турску делегацију водио је Хилми-паша.

Пре почетка главног дела прославе, митрополит Митрофан Бан је 14. августа 1910. освештао новоподигнуту зграду Владе и Скупштине, да би се у њој сутрадан одржала свечана седница на којој ће Скупштина затражити од књаза да се прихвати краљевског достојанства и уздигне Црну Гору на ранг краљевине. Цела прослава је почела 15. августа литургијом у Цетињском манастиру коју је служио митрополит Митрофан. После тога почело је заседање Народне скупштине. Председник Марко Ђукановић је рекао да посланици желе да се умоли Слављеник, у дану великог јубилеја, да обнови краљевско достојанство. Прва српска држава Светог краља Владимира настала је на територији Црне Горе, потом Зета, дедовина Стефана Немање, а зетски господар Иван Црнојевић се није приклонио судбини осталог српског народа те није признао турску власт, већ се склонио и вековима борио на последњој стопи српске земље и чувао последњу искру српске слободе и независности. После Ђукановића говорио је председник Савета Лазар Томановић. Слично као и Ђукановић, беседио је о српској краљевини и историји српства у Црној Гори. Књажевина која је на Балкану увек била прва у борби за крст часни има право да се уздигна на ранг краљевине. Напредак Црне Горе је неоспоран, а њени успеси су на углед у целој Европи, уз подршку братске Русије. Поновљена је теза о средњовековној српској држави на територији Зете, Рашке и Захумља, као доказ континуитета, односно обнове црногорске краљевине. Цетињска митрополија, наставио је Томановић, једина је светосавска епископска столица, која је очувана

Цетиње је врло лако пратило догађаје у Турској преко избеглих Срба из поглавито Беранске нахије. У прилог овој тези иде и податак да су Русија и Црна Гора потписале тајни споразум 17. новембра 1910. По својој суштини овај уговор је нарочито био значајан за будуће наоружавање црногорске војске. Руска влада се обавезала да ће црногорској војсци обезбедити опрему, наоружање, медицински материјал, а новчано се помагао и буџет саме Црне Горе. Ниједан војни путез Цетиња не сме се догодити без претходног знања царске владе. Такође Црна Гора се обавезује да на позив Русије стави своје војне снаге на располагање царској војсци. У време рата у црногорској војсци борави руски генерал у својству начелника штаба, док је краљ и даље врховни командант армије. У пролеће 1911. појавили су се руски војни и инструктори на Цетињу (Никола Шкеровић, Црна Гора на освитку 20 вијека, 559-560, 562-565).

9 У говору начелник општине Дрљевић је рекао да је ова српска престоница срећна што у великом српском слављу поздравља Србију и Црну Гору, а српски народ Великом слављенику додаје најсјанији алем у српској круни. Ипак, атмосфера у вези са посетом престолонаследника Александра била је крајње напета. Штампа је била препуна натписа о лошим односима две династије после процеса 1908-1909. Сматрало се да Србија не гледа са одобравањем на обнову краљевине у Црној Гори. Међусобне оптужбе које су изрицане током година уочи јубилеја нарушиле су покушаје јединства српских држава. Према тврдњама Србобрана, грађани Цетиња су покушавали да искажу своје незадовољство престолонаследнику Александру, али су их жандарми растерали. Иако су дед и унук (књаз Никола и Александар Карађорђевић) деловали срдачно, чини се да ситуација ипак није била до те мере позитивна. Краљевина Србија није желела да покаже анимозитет према Црној Гори, са друге стране у свом обраћању књаз је похвално говорио о својој породици у Србији и Српству уопште. Ипак, односе је можда најбоље одсликавао интервју престолонаследника Александра римској штампи. У разговору за лист Tribune престолонаследник Александар је одбацио све тврдње како је у Београду са негодовањем дочекана вест о проглашењу Црне Горе за краљевину. «Свака српска и црногорска радост и бол су заједничке, а мој ђед је украшен генералском униформом српске војске и носи највиши српски орден Св. Саве». Ипак, престолонаследник није имао одговор на питање када ће краљ Никола посетити Београд (Јован Маркуш, Краљевина Црна Гора, 103-104; Velimir Vujačić, Obnova crnogorskog Kraljevstva, Cetinje 2010, 101-102; Србобран, бр. 17, 30. август 1910). 
без прекида и која је наследница Пећке патријаршије. Томановић је сматрао да се овој старој српској земљи мора вратити њено достојанство, а тај њен успех подржавају и велике силе, са циљем да се успостави ред и мир на Балкану, на радост целог Српства и Словенства. ${ }^{10}$

Убрзо после тога делегација Народне скупштине одлази у Двор да саопшти своју одлуку (молбу) књазу Николи. Недуго затим, владар Црне Горе се обратио посланицима говорећи да одобрава обнову старог краљевског достојанства са жељом да се крене у бољу будућност. Такође, књаз је напоменуо да је захвалан Русији и богу на овом тренутку. Црна Гора има историјско право на ово достојанство, а Српство поред краљевине у Подунављу има српску краљевину у Приморју. Словенство и Српство имају још један гарант за опстанак и напредак српског племена. ${ }^{11}$

Штампан је и проглас о проглашењу Црне Горе за краљевину. У неколико реченица је стајало да се награђује народ за храброст, пожртвовање и све напоре, а историјски се потврђује некадашња моћна прва српска краљевина. ${ }^{12}$ Истог дана Народна скупштина је изгласала Закон о проглашењу Црне Горе за краљевину, а краљ Никола га је одмах потписао. На тај начин Црна Гора је проглашена за наследну краљевину, а Никола Петровић Његош за њеног првог наследног краља. У свом говору у Двору краљ Никола је, обраћајући се посланицима, крунисаним европским монарсима и многобројним гостима, између осталог рекао да никада није сумњао у родољубље и оданост свог народа, јер је сав напредак Црна Гора остварила захваљујући таквом снажном и јаком народу. Срце народа куцало је за Српство, у вери својих предака и подршци Русије. Обновљена је краљевина немањићке Зете, а Европа на овој страни Српства има јемство мира. ${ }^{13}$ Приликом обнове краљевине, на Цетињу није било крунисања краља Николе. Такође није било ни чина миропомазања. У традицији династије Петровић Његош владичанска традиција хиротоније (примања благослова Духа Светога) трајала је више генерација, па је приликом успостављања књажевине уведена само симболичка промена (капа, порфира, скиптар). Тако краљ Никола није имао краљевску круну, а симболички на капи је носио брилијантима украшени грб Црне Горе. ${ }^{14}$

Прослава на Цетињу настављена је према предвиђеном програму још два дана. Најпре је обележена 50-годишњица брака краља Николе и краљице Милене, златни пир, са нагласком на великом значају црногорске мајке и жене и развитку и јачању Црне Горе. ${ }^{15}$ Краљица Милена је са пијететом поштована као ослонац

\footnotetext{
${ }_{11}^{10}$ Глас Црногориа, бр. 35, 15. август 1910.

${ }^{11}$ Исто.

12 Исто.

13 Глас Црногориа, бр. 36, 19. август 1910; Јован Маркуш, Краљевина Црна Гора, 125-126.

${ }_{14}$ Драгомир Ацовић, Хералдика и Срби, Београд 2008, 597-602.

15 Никола Петровић се венчао са Миленом Вукотић 27. октобра 1860, на Цетињу у Влашкој цркви, без много помпе услед жалости за покојним књазом Данилом. Званична веридба је објављена још 1853, а Милена је живела у Николиној кући од 1856, када је он отишао на школовање у Париз. Благодарење приликом прославе педесет година брака такође је обављено у Влашкој цркви од стране митрополита Митрофана. По изласку из цркве, слављеници су поздрављени са 101 плотуном. Овај важни породични јубилеј краљу и краљици су честитали Влада, представници Народне скупштине, верски поглавари Црне Горе, државни чиновници, делегације из великог броја градова, али и многобројни ратници из битака
} 
владара, она која својим ставом и речју симболише Црногорке уопште, те је у оквирима прославе посебно место посвећено истицању вредности брака. ${ }^{16}$ У вечерњим сатима у Зетском дому одржана представа је Балканска ияарища, у извођењу Хрватског земаљског казалишта. ${ }^{17}$

Трећи дан прославе на Цетињу био је посвећен педесетогодишњици владавине краља Николе Петровића Његоша. Свечани дефиле црногорске војске био је на Обилића пољани. Војници су први пут обукли нове униформе, које су шивене по угледу на руске. Више од 3000 војника учествовало је дефилеу. Краљ Никола је желео да пошаље недвосмислену поруку о снази Црне Горе и њене војске пред решавање важних питања на Балкану. Стиче се утисак да је из тих разлога приказивање снаге нове војске био централни догађај свечаности 17. августа 1910. Краљ је желео да представи целу Црну Гору у војном смислу као снагу са којом се мора озбиљно рачунати. Велике победе Црне Горе у балканским ратовима потврдиле су да смотра на Обилића пољани није била само сликања ради. После дефилеа, важно је истаћи, сердар Јанко Вукотић прочитао је проглас цара Николаја о именовању краља Николе за фелдмаршала руске војске. Свечану златну фелдмаршалску палицу владару Црне Горе је уручио велики кнез Николај Николајевич Романов. Симболика овог геста руског Двора значајно је утицала и на пораст угледа Црне Горе у Српству и шире, међу Јужним Словенима. После завршетка војних свечаности, митрополит Митрофан Бан је осветио земљиште за будући Саборни храм на Цетињу, а ктитори храма били су цар Николај и краљ Никола. Целокупна прослава на Цетињу била је на тај начин прожета истицањем значаја руско-црногорских веза и истицањем важности Русије у снажењу и јачању независне Црне Горе. ${ }^{18}$

На тај начин су завршене тродневне свечаности на Цетињу у оквиру проглашења Црне Горе за краљевину. Краљ Никола је послао и јасну политичку поруку, да се са фактором Црне Горе у решавању свих балканских питања мора рачунати. Такође, порука је упућена и осталим Јужним Словенима, па и самој Краљевини Србији. Српство има још један ослонац и још један важан центар, који неће остати ван догађаја за будуће ослобођење и уједињење. Подршка Русије и истицање симболичке везе две династије, два владара и православне цркве само је још више појачавала утисак Црне Горе у Српству.

Управо ова политичка димензија Цетињске прославе била је највише анализирана на странама пречанске штампе. Застава и Србобран у својим

\footnotetext{
Црне Горе 1876-1878 (Краљ Никола, Мемоари, Подгорица 2009, 26-30; Јован Маркуш, Краљевина Црна Гора, 164-171).

${ }_{16}$ Дан је започео литургијом коју је служио митрополит Митрофан (као духовник брачног пара), а потом су цео дан долазиле депутације које су честитале јубилеј.

${ }_{17}$ Извођење представе Балканска ицарица коју је написао књаз Никола 1881-1884, од стране Хрватског земаљског казалишта, у пречанској штампи дочекано је са негативним коментарима. Радикали су сматрали да је на тај начин краљ Никола угрозио јединство српске идеје, јер је према њиховом мишљењу представу требало да изведе Београдско народно позориште. Са друге стране мора се истаћи чињеница да je насупрот писању Заставе, приликом прославе певало Београдско певачко друштво на чело са Стеваном Стојановићем Мокрањцем (Velimir Vujačić, Obnova crnogorskog kraljevstva, Zbornik Dokumenata 167-168, 170-171, 173, 204-205, 208-212; Застава, бр. 180, 1. септембар 1910).

${ }^{18}$ Јован Маркуш, Краљевина Црна Гора, 194-199.
} 
натписима нису штедели књаза Николу. Нагласак је био на негативним странама Николине владавине. Црна Гора је у писању ова два листа проглашена за недемократску и аутократску књажевину где нису поштована основна људска и грађанска начела. Небезбедност, самовоља владиних службеника, прогон политичких противника и чак убиства огорчених непријатеља династије били су синоними за књаза-краља Николу у призми ова два листа. Као што су на страницама штампе на Цетињу наглашене манифестације које су симболисале јединство народа и династије, затим снагу економског напретка и велику подршку црногорском владару, тако су Застава и Србобран искључиво писали о свим негативним политичким чиниоцима у Црној Гори. Често су наслови или речи на страницама пречанске штампе деловали чак неумесно. Нарочито се пуно писало о односу краља Николе према Краљевини Србији, уз констатацију да је тај однос лош и непријатељски. Читаоци су на динамичан и ефектан начин били информисани о свим догађајима на Цетињу, са нагласком на чињеници да је стање у Црној Гори лоше, да је славље изрежирано и да суштински краљ Никола прави лажну слику о себи и својој владавини.

Први натписи у Србобрану о проглашењу краљевине јављају се већ током јула 1910. Бечка штампа (преноси загребачки лист) јавља да је црногорска влада решила да затражи од књаза Николе да обнови краљевину. Политички значај овог потеза лежи у томе што ће породица Петровић бити истог ранга са српском краљевском породицом у Београду. Даљи коментар уредништва Србобрана био је како Црна Гора у свом такмичењу по господству безмерно претерује, односно због чега нису главари одмах прогласили своју државу царевином, а Николи дали Душанову круну? ${ }^{19}$ На спољнополитичком плану, писао је загребачки лист, интензивира се сарадња Црне Горе и Бугарске. Никола Петровић у својим здравицама помиње Фердинанда, али не и краља Петра. ${ }^{20}$ Стање у Црној Гори је све лошије, почиње да ради инквизиција, док су прогони неистомишљеника од стране цетињских перјаника црногорска свакодневица, писало је у тиражној новини. ${ }^{21}$

Стиче се утисак да су натписи у Србобрану били усмерени директно на владавину самог књаза. Из броја у број се писало похвално о црногорској омладини или њеним напредним идејама, а обнова краљевине тумачена је само као беспотребни хир Николе Петровића који шкоди Српству. Стање у Црној Гори не може поправити скупа и испразна титула, цетињски зликовци сада планирају да шаљу своје убице по Старој Србији, Турској и чак до Америке, да ликвидирају своје непријатеље (у Америци је тада боравио Симо Шобајић) - био је један од уобичајених натписа. ${ }^{22}$ Ширене су и непроверене информације, да је паника и страх

\footnotetext{
${ }^{19}$ Србобран, бр. 137, 2/15. јул 1910.

${ }^{20}$ Србобран, бр. 147, 14/27. јула 1910

${ }_{22}^{21}$ Србобран, бр. 148, 15/28. јул 1910.

22 Симо Шобајић је био један од осуђеника на доживотну робију на процесу вођеном маја-јуна 1908. Наводно је у Београду пред сведоцима рекао: Мене је књаз Никола осудио на смрт, али и ја њега. На смрт су осућени: Тодор Божовић, Марко Даковић, Јован Ђоновић, Петар Новаковић, Ђуро Војводић и Васо Ћулафић (Никола Шкеровић, Црна Гора на освитку 20 вијека, 419-421; Србобран, бр. 155, 24. јула / 6 . августа 1910).
} 
у редовима владе и да је цела војска мобилисана у источној Црној Гори, јер се чуло да Никола Митровић покушава да организује групу и изврши побуну у данима прославе на Цетињу. ${ }^{23}$

Под насловом Око јубилеја објављен је 162 број Србобрана, који је за главну тему имао свечаности на Цетињу. Расположење Црногораца је приказано тамним бојама, уз напомену да становништво на овај јубилеј не гледа са одобравањем. Министарство полиције спремило је спискове и послало по капетанијама да се организују људи за Цетињску прославу, и да се строго нареди на који начин се исти морају понашати, шта имају рећи и да буду што орнији за народно весеље. Подељена је и цркавица сиромасима, да имају шта да поједу подно Орлова крша. Депутације се морају обући по правилима, што свечаније и помпезније, пошто прослава мора бити гламурозна, писало је у Србобрану. Нарочито су финансијски пострадали Херцеговци и Бокељи. О бесплатној храни, која треба да сведочи о благостању нове краљевине, да не пишемо, јер је то недостојно. Сваки паметан човек може на догађај на Цетињу са презрењем пљунути, био је закључак на страницама самосталског листа. ${ }^{24}$ Донет је и натпис о протестима омладине. Црногорска академска омладина из Београда упутила је жесток протест поводом Николиног јубилеја и пира на Цетињу. Овакав јубилеј није симбол никаквог друштвеног ни националног успеха. Лажни спољашњи сјај служи као маскарада да прикрије све слабости једног недемократског режима. Обезглављени народ мора да се радује и кличе, али више му је до кукања и плача. Пир је обележен крвљу мученика и злочином према народу. Јубилеј је врхунац безумља, који осуђујемо, стајало је у прогласу. ${ }^{25}$

Слично се писало и на страницама новосадске Заставе. Често погрдно и неумесно књаз Никола је описан као тиранин, који је подигао целу земљу због свог личног хира. Под насловом Црна Гора-краљевина, крајем јула пренета је информација о уздизању Књажевине на виши државно-правни статус. Вести стижу у Нови Сад, да ће 19. августа Црна Гора бити на Скупштини проглашена за краљевину. Скупштина ће умолити кнеза Николу да се прихвати краљевске титуле. Никола неће желети да се замери скупштини па ће прихватити. Да ли ће црногорском народу на тај начин бити боље, то се наравно народ и не пита. Неколико дана пошто је стигла вест да је кнез Никола донео одлуку да се прихвати краљевске титуле, долазе и информације да је владар Црне Горе решио да предузме путовање по Европи. Посетиће све владаре и европске дворове, уз посету и Београду, како тврди руска штампа. У Санкт Петербургу пишу да је Никола на тај начин решио да убрза помирење српских династија које се прижељкује у самој Русији, иако је краљ Петар изјавио да неће путовати у августу на Цетиње, писао је лист Српске радикалне странке. ${ }^{26}$

\footnotetext{
${ }_{23}^{23}$ Србобран, бр. 156, 26. јул / 8. август 1910.

${ }_{24}^{24}$ Србобран, бр. 162, 3/16. август 1910.

${ }^{25}$ Србобран, бр. 173, 17/30. август 1910.

${ }^{26}$ Црна Гора - краљевина, Застава, бр. 147, 8/21. јул 1910; Застава, бр. 149, 23. јул 1910, Црногорска београдска студентска омладина такође је потписала проглас против проглашења Црне Горе за краљевину. У прогласу је стајало да је народ у Црној Гори непросвећен, необавештен, терорисан, и да не
} 
Слично као у Србобрану, уочи саме манифестације појавио се чланак који је у својој анализи црногорске политичке сцене жестоко напао књаза. Под насловом Цетињски крволоци на страницама Заставе стајало је да се сав поштени свет на вест проглашења Црне Горе за краљевину и књаза Николе за краља надао бар једној лепој вести како ће се сунце слободе осмехнути и жртвама цетињске тираније. У тамници труну најбољи синови Црне Горе, услед афере о подметнутим бомбама. Цетињски крволоци нису задовољни. Спремни су за нова злодела и крволоштва уочи славља књаза Николе - јадно му славље, уочи славља Црне Горе - јадно јој славље. Синови Куча одавно су трн у оку цетињских крволока. Томановићева влада задала је велику рану племену Куча, па сад стрепи од освете. Стрепи од буре коју је посејала својим насиљем и крволоштвом. У Подгорици је ухапшен Лазар Рашовић Вујашевић из племена Куча. Неколико година је провео ван земље, учећи школе. Пре него што је и стигао до куће, жандарми су га ухапсили и одвели у Јасовачу. Влада тврди да је ухапшен зато што је под псеудонимом Виктор у бечкој Зори писао лоше о стању у Црној Гори, иако је параграф 210 Устава Црне Горе дозволио слободу штампе. Црногорским крволоцима се привиђају капетан Иван Петровић и мајор Никола Митровић, који наводно спремају упад из Албаније. Лазар је Иванов рођак, па отуда и хапшење, јадна Црна Горо, јадно ти славље! Тако је у овом жестоком нападу на књаза Николу стајало у новинама новосадских радикала. ${ }^{27}$

Колумна под насловом Цетиғска прослава пише о атмосфери и изгледу Цетиња пред почетак ове велике манифестације. Престоница је окићена свечаним рухом и заставама. Народ Црне Горе притеран властима и перјаницима учествује телом у прослави, али да ли учествује и душом. Тамнице су препуне његових синова, народ изложен беди, прогањању, па и животи нису сигурни. Народ би пре ишао на парастос или даћу, да оплакује своју судбину и судбину своје домовине. Но, заповест перјаника и жбирова мора се слушати, иначе ће кућа над главом бити згариште, а народ плаћа главом или одлази у тамницу. Мајор Митровић је убијен у Скопљу по налогу црногорске владе, пре почетка свечаности. Сви који су стајали иза Митровићевог убиства у Скопљу пуштени су на слободу. Нема помиловања за политичке осуђенике, њих 48 у Јусовачи. А да је кнез Никола волео свој народ, не би доводио Томановићеву владу, и не би водио хајку на своје најбоље синове и свој народ. Чини се да црногорски народ неће добити светлије дане овим проглашењем. Имаће да издржи још тежих и горких искушења и очајне борбе док не створи за себе и домовину бољу судбину. ${ }^{28}$

сме да изрази незадовољство о овом акту књаза Николе. Режим је критикован због недемократских метода владавине и лошег стања у самој Црној Гори. Проглашење краљевине није симбол никаквог напретка већ искључиво политичке жеље Цетиња да се забораве афере, беда, немаштина и процеси против грађана Црне Горе (Никола Шкеровић, Црна Гора на освитку 20 вијека, 552-554).

${ }_{27}$ Застава, бр. 159,5 . август 1910.

${ }^{28}$ Застава, бр. 170, 18. август 1910. Иза убиства мајора Митровића стајао је Стеван Ристов Которанин из Призрена, пореклом из Црне Горе. После пресуде суда у Колашину (смртна казна) Митровић је затражио азил. Живео је у хотелу «Империјал» у Скопљу. Нападнут је камом у хотелској соби ноћу 31 . јула, а од последица рана је преминуо 25. августа. Окривљени су конобар из хотела Ставра Николић, Стеван Которанин (Которчевић) и власник хотела Тодор Јовановић. Државни тужилац их је именовао као агенте црногорске владе. Председник Владе Јован Пламенац сматрао је да се акција прогона противника режима мора наставити и ван Црне Горе. Тако је његов пашеног Станко Марковић био ангажован да уништи 
Застава није штедела ни своје политичке противнике у Монархији. Пренета је вест из Будимпеште да је Пештер Лојд писао о томе да је на Цетињу поводом 50 година владавине књаза Николе говорио Михаило Полит Десанчић. Застава је додала иронично: сада Полит може да се братими са бураским краљем и почне све своје здравице речима: када сам био на Цетињу и братимио се са бугарским краљем... ${ }^{29}$ Овај коментар Заставе у погледу боравка Михаила Полита Десанчића на Цетињу симболички представља и однос две странке (радикала и либерала) и њихова два листа (Заставе и Браника) према Црној Гори и јубилеју. На прву вест о обнови краљевине Браник је афирмативно констатовао како се Црна Гора радује (цео народ од Дурмитора до Бара и Дечана), а витешки књаз Никола прославља и јубилеј своје владавине. Црна Гора је за српску слободу поднела велике муке, док њен владар води рачуна о држави и свом народу, те његова круна симболише и јединство и душу народа, али и династије. Он као владар зна да му круна није потребна, она је потребна народу као ново достојанство и нова награда. Цела Црна Гора и Српство и Словенство са радошћу ће поздравити овај догађај, писало је у Бранику. ${ }^{30}$

Такође, треба се осврнути и на текст Кнез Никола као српски владар, објављен у листу Neue Freue Presse. ${ }^{31}$ Иако овај лист није поглавито просрпски расположен, ипак је пренео новости о томе да је Никола владар који је знао да задобије углед целе Европе својим делима и шире брачним везама; најпре је затражио дозволу европских владара и потом прогласио своју земљу краљевином. Он није желео да заостане за својим зетом, па ни бугарским и румунским владарем, а његов углед и значај дали су му за право да тако и поступи (Гледстон је именовао књаза Николу за најдаровитијег међу својим познаницима, а цар Александар III јединим верним пријатељем Русије). Он је дипломата, ратник, политичар, песник, речју, личност великог значаја, пренео је Neue Freue Presse. Црна Гора тек у време његове владавине почиње да се развија као модерна држава. После овог текста срамота је да цела Европа хвали српског кнеза, а да га неки блате, констатује Полит Десанчић. ${ }^{32}$

У чланку Црна Гора и Србија, објављеном у Бранику, сматрало се бесмисленим објашњење краља Петра да не путује на Цетиње јер није добио званичан позив. Слављеник прима честитања, а не шаље позиве! Пашић на такав начин забија гвоздени клин између две српске државе. Некоректан и несрпски поступак Владе у Београду, констатовано је на страницама либераског листа. ${ }^{33}$ Издвајамо и чланак На Цетиње, у којем стоји како је брука што српски краљ не долази у посету будућем српском краљу, јер ове свечаности су од великог интереса

емигранте Тодора Божовића и Јована Ђоновића (Никола Шкеровић, Црна Гора на освитку 20 вијека, 547-548).

29 Застава, бр. 174, 24. август 1910.

${ }^{30}$ Браник, бр. 147, 6/19. јул 1910.

${ }^{31}$ Исти текст је пренет и на страницама Србобрана, али без дела који је афирмативно писао о књазу и његовој владавини.

${ }^{32}$ Браник, бр. 148, 7/20. јул 1910.

${ }^{33}$ Браник, бр.149, 9/ 22. јул 1910. 
за цело Српство. Велике силе знају да књаз Никола не жели да учини ништа непромишљено на Балкану, што је и подстакло европске кругове да подрже његов чин. Сваки поштени Србин мора бити задовољан. Невероватно је да са српске стране излазе прогласи (Омладине) који на најодвратнији и најнедостојнији начин нападају прославу и поручују Србима да се не иде на Цетиње. Мора се мислити на Николину педесетогодишњу владавину у име Српства. Са мајушним средствима ова држава је победница 1876-1878, и кренула је у процес унутрашње изградње. Зар је само бомбашка афера разлог оваквим нападима и потирању велике улоге Црне Горе у борби за Српство? ${ }^{34}$ Браник је у низу бројева, 173-178, 180, 182-183, 184, преносио званичне вести о делегацијама и посетама, као и званичне објаве о проглашењу краљевине, затим Прокламацију краља Николе и остала званична саопштења са Цетиња.

Писало се и о томе да је Михаило Полит Десанчић срдачно дочекан на Цетињу, да су га примили владара и председник Савета. ${ }^{35}$ Говор Михаила Полита Десанчића на Цетињу посебно је одисао политичком идеологијом вође либерала и идејама о односу Србије и Црне Горе, и шире: месту Црне Горе у Српству. На почетку Полит је поменуо свој боравак на Цетињу 1860. и велике победе црногорске војске које су уследиле у ратовима 1876-1878. Данас Црна Гора (коју су некада називали војничким логором) има развијене све сегменте друштва, она је средиште балканске политике, а њен владар је стекао поверење целе Европе. Црна Гора је својим конзервативизмом очувала највредније традиције Српства. Нама Србима у Монархији, каже се, најбитиније јесте да краљ Црне Горе има добре односе са Царевином, и за нас нема веће радости него да цела Европа уважава Николу Петровића. Стога поздрављамо српског јунака, државника, песника и дипломату, беседио је Полит. ${ }^{36}$

Други новосадски лист писао је сасвим супротно. Лист пречанских радикала није, стиче се утисак, поштовао ни основне норме пијетета према владару једне суверене државе. Застава је објавила песму која је описивала Николину владавину најцрњим бојама, а уз речи и строфе чувене химне Онамо, намо коју је написао књаз још 1867, и којом је читавом Српству ставио до знања да је Косовска легенда (како је и сам често говорио - аманет) један од стубова његове владарске идеологије. ${ }^{37}$

\footnotetext{
${ }^{34}$ Браник, бр. 166, 1/14. август 1910.

${ }_{35}$ Браник бр. 179, 20. август / 2. септембар 1910.

${ }^{36}$ Браник, бр. 186, 29. август / 11. септембар 1910. Михаило Полит Десанчић је у више бројева Браника (189-193) објавио и своје личне утиске о боравку на Цетињу под насловом После педесет година на Цетиғу, где је похвално писао о владавини краља Николе и генерално напретку који је Црна Гора остварила у економији, правосуђу, изградњи путева, али и придобијањем нових области после ратова $1876-1878$.

${ }^{37}$ У својим многобројним беседама, прокламацијама и кроз писану реч, Ккраљ Никола Петровић Његош је истицао освету Косова и Васкрс српског царства, као важне сегменте своје владарске идеологије. Приликом поласка црногорске војске 1876. у рат са Турском, примера ради, управо је цела атмосфера одисала испуњењем косовског завета. Веза Црне Горе са државом Немањића важан је фактор у континуитету државности и представља кључну чињеницу не у успостављању, већ у обнови Краљевине Црне Горе. Истицање Српства у говорима господара Црне Горе на прослави 1910. имало је и јасну поруку Влади у Београду. Цетиње има своју улогу у обнови некадашње Душанове државе. Црна Гора је током дугог низа година, нарочито код пречана, сматрана јединим делом слободног Српства који баштини
} 
Онам', онамо... за брда она,

Гдје Ловћен грли Владичин гроб,

Онамо нема правде, слободе -

У својој земљи Србин је роб!...

Онам', онамо... Тамнице пуне

Синцима првим: метн'о их кнез

Мемла их бије и кост им трухне,

Кнез својом руком притеже вез..

Онам', онамо... за брда она

Чује се вапај, пригушен плач:

То седи владар припрема славље -

За дјеиу своју он оштри мач..

Онам, онамо... за брда она

Био је негда јуначки збор;

Данас је сјен од краљевског трона,

А око њега најмљени хор...

Онам', онамо... из развалине

Части и славе нагрно ирв,

Што прије да их у блато срине,

И да им пије јуначку крв...

Онам', онамо... за брда она

Кнез данас страшни пирује пир:

Ода свуд јаче погребна звона,

На сваки корак ври крви вир...

Видиш ли, кнеже, праву крв ову?!..

Чујеш ли, кнеже, погребни јек?! -

Неопојани гробови зову,

Вапије правду окова звек:

„Докле ћеш, кнеже?!... Зар није доста?!..

„Над главом палиш рођени дом!..

„Крв и тамница нек ти је проста -

„, Врати се, кнеже, народу свом!... ${ }^{38}$

Овакав напад на цетињску прославу свакако је био један од најжешћих у пречанској штампи. Поставља се питање да ли је оваквим ставом Застава наносила више штете радикалној странци у Аустроугарској, Краљевини Србији или самој Краљевини Црној Гори?

Читаоци Заставе читали су и о томе да је петроградски лист Реч писао о односима Србије и Црне Горе. У чланку се говори и о томе ко је кривац за раздор

немањићке традиције. Са тог аспекта, политичко-филозофска мисао Николе Петровића представља незаобилазни фактор српске и балканске политике током читавих пет деценија (Вид.: Краљ Никола, Говори, Подгорица 2009, 13-17, 19, 21-22, 27-34, 36-38, 46, 62-69, 76-80, 93-100).

${ }_{38}$ Застава, бр. 178, 30. август 1910. 
међу српским владалачким породицама. Према аутору текста, главна одговорност је на краљу Николи. После смрти краља Александра Обреновића он је желео да на престо Србије дође његов син Мирко Петровић. Србијанци, ценећи Карађорђа, желели су да има владар буде Петар Карађорђевић, а не апсолутистички васпитани црногорски кнежевић. Кнез Никола тада јесте послао Мирка на крунисање, али је зато добио 200.000 динара. Када је руски цар изразио жељу да краљ Петар дође на Цетињску прославу, депеша са позивом од кнеза Николе владару Србије није стигла. Према писању Речи, у Анексионој кризи Никола је играо двоструку улогу, затим је од краља Петра тражио да испоручи Црногорце побегле у Србију приликом афере са бомбама. Имовински краља Петра је такође оштетио Никола Петровић. Када се Зорка удавала за Петра, мираз је дао руски цар и био је намењен Петровој деци, али није исплаћен, а Петров двор у Бару такође је присвојио Никола, пренео је новосадски лист. ${ }^{39}$

На такав начин је завршено писање српских пречанских листова о проглашењу Црне Горе за краљевину и јубиларним свечаностима на Цетињу. Владарска и политичка идеологија краља Николе, која је основу имала у Косовској легенди, Васкрсу српског царства и везама са Русијом, није наишла на одговарајуће место у Застави и Србобрану. ${ }^{40}$ Владар Црне Горе критикован је због аутократског начина управљања државом, због слабих политичких слобода или односа према опозицији, нарочито после Бомбашке афере и Колашинског процеса. Мало простора у овим листовима је посвећено успесима Николине владавине - територијалним проширењима или модернизацији државе и државне управе. Краљ Никола нарочито је оптужен за лоше односе са Краљевином Србијом и неретко је проглашаван за главног кривца. У колумнама на страницама Заставе и Србобрана је писало како је за Српство боље да има један центар окупљања. Либералски Браник није сматрао да је то природно стање ствари. Величајући Црну Гору и њеног господара, Михаило Полит Десанчић је покушавао да докаже како су Српству неопходни слога, јединство и равноправност Цетиња и Београда! Његова мисао до данас није изгубила на актуелности.

\footnotetext{
${ }^{39}$ Застава, бр. 183, 4. септембар 1910.

40 Занимљив је став новије црногорске историографије о политици краља Николе и Цетињској прослави уопште. Никола I је окарактерисан као искусан политичар који је покушавао да у име ослободилачке мисије своје земље прикрије хегемонистичке претензије на суседне народе православног верског обреда. Такође, прогласи Црногорске универзитетске омладине, који су писали против књаза, сматрају се антицрногорским плановима иза којих је стајала званична Србија, са циљем да се поткопа углед Црне Горе и њеног владара. Чак се разматрало насилно укидање црногорске династије и рушење црногорске државе, која је требало да постане колонијални привезак Краљевине Србије. Црногорско српство краља Николе тумачи се чињеницом да је Турска била слаба и да је на њеним развалинама било могуће извршити територијално проширење. На тај начин, уз фактор Русије која је била други чинилац Николине политике, српство је било начело које је конципирао и практично изводио, уз циљ стварања православне државе на Балкану (Velimir Vujačić, Obnova crnogorskog Kraljevstva, Cetinje 2010, 8, 30, 41-42).
} 


\section{Извори и литература:}

Извори:

Периодика: Застава, Браник и Србобран

Вуковић, Гавро, Мемоари, књ. 1,Цетиње-Титоград 1985.

Поповић, Симо, Мемоари, Подгорица 1995.

Петровић, Његош Никола, Говори, Подгорица 2009.

Петровић, Његош Никола, Мемоари, 1-2, Подгорица 2009.

Литература:

Ацовић, Драгомир, Хералдика и Срби, Београд 2008.

Vujačić, Velimir, Obnova crnogorskog kraljevstva i jubilarne svečanosti 1910, Cetinje 2010.

Крестић, Василије, Љушић, Програми и статути српских политичких странака до 1918, Београд 1991.

Љушић, Радош, Српска државност 19 века, Београд 2008.

Маркуш, Јован, Народна странка у Црној Гори 1906-1918, Подгорица 2006.

Маркуш, Јован , Краљевина Црна Гора, споменица јубилеја 1910-2010, Подгорица 2010.

Педесет година на престолу Црне Горе, Цетиње 1910.

Ражнатовић, Новица, Лична власт књаза и политичке борбе, у: Историја српског народа, VI/1, Београд 1994.

Шкеровић, Никола, Црна Гора на освитку 20 вијека, Београд 1964. 
GORAN VASIN

\title{
PREČANI PRESS ON PROCLAMATION OF THE KINGDOM OF MONTENEGRO
}

\begin{abstract}
Summary
Proclamation of the Kingdom of Montenegro was in the spotlight of Prečani press. The most influential newspapers Zastava, Srbobran and Branik wrote about the event for several weeks in each issue. The newspapers of Novi Sad radicals and Zagreb independents were leading in their criticism of the rule of King Nikola. They characterized him as an autocrat and a tyrant who suppressed political freedom and hindered the development of Montenegro. From a political point of view, they felt that such a move of the ruler of Montenegro was only an attempt to satisfy personal vanity, which caused a great damage to the Serbian idea. Unlike Zastava and Srbobran, the newspapers of Prečani Liberals, Branik, wrote about the rule of Nikola Petrović with reverence. There was glorified his role in the overall fight for the Serbian idea and emphasized s need for unity of the two Serbian Kingdoms.
\end{abstract}

Keywords: Montenegro, Nikola Petrović Njegoš, Kingdom, celebration, Cetinje, Russia, Prečani, the press. 